\title{
Differences in Maternal Leptin Serum Levels between Normal Pregnancy and Preeclampsia
}

\author{
Yusrawati $^{1, *}$, Ratna Lestari Habibah ${ }^{2}$, Rizanda Machmud ${ }^{3}$ \\ ${ }^{1}$ Division of Fetomaternal, Department of Obstetrics \& Gynecology, Medical Faculty of Andalas University, Jl. Perintis Kemerdekaan No.94, Padang, \\ Sumatera Barat, Indonesia \\ ${ }^{2}$ Department of Obstetrics \& Gynecology, Medical Faculty of Andalas University, Jl. Perintis Kemerdekaan No.94, Padang, Sumatera Barat, Indonesia \\ ${ }^{3}$ Department of Public Health, Medical Faculty of Andalas University, Jl. Perintis Kemerdekaan No.94, Padang, Sumatera Barat, Indonesia \\ *Corresponding author. E-mail: yusrawati_65@yahoo.co.id
}

\section{Abstract}

$\mathrm{B}$ ACKGROUND: Maternal circulating leptin, placental leptin gene expression, and protein levels are increased in preeclampsia as compared with those in normal pregnancy. Increased serum leptin levels in preeclampsia which correspond with increased gestational age can be used independently or with other parameters as a marker for the severity of preeclampsia. The advantages of this examination in identifying preeclampsia severity are its simplicity, fast result, low cost, and applicability.

METHODS: A cross-sectional study was conducted in delivery room, polyclinic of Dr. M. Djamil Hospital, and Biomedical Laboratories of Medical Faculty of Andalas University from December 2013 to April 2014. The samples were collected from 68 women with singleton pregnancy in their third trimester $(>28$ weeks) presenting to the polyclinic and the delivery room of Dr. M. Djamil hospital. Differences in maternal serum leptin between preeclampsia and normal pregnancy were determined using t-test and Wilcoxon test for data with and without normal distribution, respectively, where $p<0.05$ indicating a significant results.

RESULTS: The mean maternal serum leptin levels in normal pregnancy and preeclampsia were $1588.7964 \pm 8.01074$ $\mathrm{ng} / \mathrm{mL}$ and $1608.1725 \pm 6.69579 \mathrm{ng} / \mathrm{mL}$, respectively. Thus, there is a statistically significant difference in mean maternal serum leptin levels between the normal pregnancy and preeclampsia $(p<0.05)$.

CONCLUSION: There are significant differences in maternal serum leptin levels between women with normal pregnancy and preeclampsia.

KEYWORDS: leptin, preeclampsia, pregnancy

Indones Biomed J. 2015; 7(1): 37-42

\section{Introduction}

Preeclampsia is a form of hypertension complicating $2-8 \%$ of all pregnancy worldwide, and plays a major role in intrauterine growth restriction, premature delivery, as well as maternal and fetal morbidity and mortality. Preeclampsia is believed to develop during early pregnancy and eventually manifest as endothelial dysfunction and/ or vascular dysfunction which leads to hypertension.(1,2) Preeclampsia is a condition which could progress rapidly and characterized by increased blood pressure, edema, and proteinuria. When undetected, preeclampsia may turn into eclampsia which is one of the causes of maternal and fetal morbidity and mortality, and contributes for $13 \%$ of all maternal death worldwide.(2) In Indonesia preeclampsia 
and eclampsia are responsible for $30-40 \%$ of perinatal deaths.(3) A study in 2002 in Dr. M. Djamil Hospital located in Padang, showed that the prevalence for preeclampsia and eclampsia were $5.5 \%$ and $0.88 \%$, respectively. From those $5.5 \%$ of severe preeclampsia cases, $65 \%$ occurred in term pregnancy.(4) Data for severe preeclampsia patients in Dr. M. Djamil Hospital revealed that there were 27 patients in 2008, and it increased almost 3 folds (70 patients) in 2009. In 2010, pregnant patients with gestosis complication were 176 patients, 140 patients of those had severe preeclampsia and 36 patients had eclampsia. From 140 patients who had severe preeclampsia, 3 patients evolved into disseminated intravascular coagulation (DIC) and 2 patients developed stroke.(5) In 2011, 137 patients had severe preeclampsia and 24 patients had eclampsia. In 2012, 158 patients had severe preeclampsia and 73 patients had eclampsia, which means there is approximately $11.4 \%$ increase from the previous year.(5) Therefore early concern is necessary for pregnant women with this condition. $(6,7)$

Leptin is a peptide hormone that is synthesized from adipose tissue and represents a product from obesity gene found in human and rodent.(8,9) Being secreted predominantly from white adipose tissue, leptin is also synthesized in several non-adipose tissue including trophoblast of human placenta. Leptin generally acts as a factor for the feeling of satiation from fat cells, which are involved in regulation of food intake and energy consumption. Recent study showed that leptin has a wide variation in its biologic effect on neuroendocrine and reproductive function.(10) Leptin stimulate inflammatory response via proinflammatory cytokine induction in placenta and adipose tissue. Leptin also induced lipid peroxidation in human endothelial cell culture, and thus leptin is thought to facilitate atherogenesis in preeclampsia.(11)

Placental leptin is stimulated by hypoxia, which is increased in eclampsia and may affect the fetal outcome. The level of mRNA leptin and protein in adipose tissue and placenta is positively correlated with body fat and the size of adiposity. Therefore, obese individuals have higher leptin mRNA and protein level than non-obese individuals. For example, leptin in non-pregnant normal women decreases during fasting, which indicates that leptin has negative correlation with body fat decrease. Meanwhile leptin mRNA and protein increase several hours following food consumption. This nutritional effect is mediated at least partly by insulin, as seen in direct stimulation by leptin synthesis and release when adipocyte is preserved by insulin. In human and rodent, increased postprandial leptin corresponds to the peak of insulin secretion. On the other hand, insulin deficiency may result in rapid decrease of protein and mRNA leptin.(12)

Circulating maternal leptin, placental leptin gene expression and protein level are increased in preeclampsia as compared to those in normal pregnancy.(13) In normal pregnancy, serum leptin concentration increases with the increase of maternal body weight and is negatively correlated with maternal body height, but is not influenced with other maternal factors such as age, race, parity, smoking, or contraception method. In previous study, circulating maternal leptin concentration was reported to increase in preeclampsia.(14) Severe preeclampsia is correlated with abnormal trophoblast invasion that results in blood flow alteration in subplacental artery, increased placental blood flow and umbilical artery resistance as well as fetal growth retardation.(15) It can be concluded that placental hypoxia in severe preeclampsia will induce an increase in leptin level and this increament may occur prior to the clinical onset of the disease. The increased plasma leptin level in preeclampsia in association with gestational age can be used independently or with other parameter as a marker for preeclampsia severity.(16) The other benefits of this leptin examination are its simplicity, fast result in detecting preeclampsia severity, affordability and applicability.

Therefore, in present study we would like to investigate the differences between the increase of maternal serum leptin level in normal pregnancy and that in preeclampsia.

\section{Methods}

We conducted a cross sectional study to identify the difference between maternal serum leptin level in preeclampsia and that in normal pregnancy. The study was conducted in delivery room and polyclinic of Dr. M. Djamil Hospital as well as Biomedical Laboratory of Medical Faculty of Andalas University. The study was performed from December 2013 until April 2014. The inclusion criteria include a singleton pregnancy in third trimester $(>28$ weeks) and agreement to take part in the study. Whereas the exclusion criteria include chronic hypertension, diabetes mellitus, chronic liver disease, chronic kidney disease, multiple pregnancy, and acute infectious disease.

Venous blood was drawn up to $3 \mathrm{cc}$ without anticoagulant, transferred to a vacutainer tube and 
centrifuged for approximately 15 minutes at 1000 round per minute (rpm) to obtain its serum. Leptin concentration was then quantified with xMark $^{\mathrm{TM}}$ Microplate Absorbance Spectrophotometer (Bio-Rad, Hercules, CA, USA). The statistical analysis used to identify the difference between maternal serum leptin level in third trimester pregnancy ( $>28$ weeks) in preeclampsia and normal pregnancy is t-test for data with normal distribution and Wilcoxon test for data without normal distribution.

\section{Results}

We conducted a study to identify the difference of leptin level between women with normal pregnancy and preeclampsia in third trimester pregnancy. The total number of women included was 68, which were divided into 2 groups: 34 normal pregnant and 34 preeclamptic women.

\section{Sample Characteristic}

Sample characteristic of 68 samples, based on age, gestational age, parity, body mass index (BMI), and birth weight was shown in Table 1. Based on the age of respondents with normal pregnancy, the average was $30.1471 \pm 5.86273$ years old. Meanwhile the average age of preeclamptic women was $30.8529 \pm 7.42287$ years old. There was no significant difference for age distribution in both groups $(p>0.05)$.

Sample characteristic of this study based on the BMI of normal pregnant women has the average value of 22.7294 $\pm 2.92943 \mathrm{~kg} / \mathrm{m} 2$. In preeclamptic women, the average value was $23.4209 \pm 3.28739 \mathrm{~kg} / \mathrm{m} 2$. There was no significant difference statistically in the BMI distribution between the two groups $(p>0.05)$. Sample characteristic based on parity for nulliparous normal pregnant women was $13(38.2 \%)$ which is higher than $12(35.3 \%)$ nulliparous preeclamptic women from the total sample of $25(36.8 \%)$ nulliparous pregnant women. However, there were 21 (61.8\%) multiparous normal pregnant women as compared to $22(64.7 \%)$ multiparous preeclamptic women from a total sample of $43(63.2 \%)$ multiparous pregnant women. There was no significant difference in parity distribution $(p>0.05)$. Sample characteristic of the study based on gestational age showed that there were $6(17.6 \%)$ preterm normal pregnant women as compared to $11(32.4 \%)$ preterm preeclamptic women from a total of $17(25 \%)$ preterm pregnant women. On the other hand, there were $28(82.4 \%)$ term normal pregnant women and $23(67.6 \%)$ term preeclamptic women from a total sample of 51 term pregnant women. There were no significant statistic difference in the distribution of gestational age $(p>0.05)$.

Sample characteristic of the study based on birth weight was $3059.8235 \pm 427.22058$ gram in normal pregnant women and 2591.1765 \pm 890.98776 gram in preeclamptic women. There was a significant difference in the distribution of birth weight $(p<0.05)$.

The Difference in maternal serum leptin level between preeclampsia and normal pregnancy

As described in Table 2, there was difference in maternal serum leptin level between preeclampsia and normal

Table 1. Sample Characteristic of the Study.

\begin{tabular}{llcccc}
\hline & \multicolumn{1}{c}{$\begin{array}{c}\text { Normal } \\
(\mathbf{n = 3 4})\end{array}$} & $\begin{array}{c}\text { Preeclampsia } \\
(\mathbf{n = 3 4})\end{array}$ & Total & $\boldsymbol{p}$ \\
\hline $\begin{array}{l}\text { Age } \\
\text { (years old) }\end{array}$ & $30.1471 \pm 5.86273$ & $30.8529 \pm 7.42287$ & $\mathbf{0 . 6 6 5}$ \\
\hline $\begin{array}{l}\text { BMI } \\
\text { (Kg/M2) }\end{array}$ & $22.7294 \pm 2.92943$ & $23.4209 \pm 3.28739$ & $12(35.3 \%)$ & $25(36.8 \%)$ & $\mathbf{0 . 3 6 3}$ \\
\hline Parity & Nulliparous & $13(38.2 \%)$ & $22(64.7 \%)$ & $43(63.2 \%)$ & $\mathbf{1 . 0 0 0}$ \\
\cline { 2 - 5 } & Multiparous & $21(61.8 \%)$ & $11(32.4 \%)$ & $17(25 \%)$ & \\
\hline Gestational Age & Preterm & $6(17.6 \%)$ & $23(67.6 \%)$ & $51(75 \%)$ & $\mathbf{0 . 2 6 2}$ \\
\cline { 2 - 5 } & Term & $28(82.4 \%)$ & $2591.1765 \pm 890.98776$ & & $\mathbf{0 . 0 0 7}$ \\
\hline $\begin{array}{l}\text { Birth Weight } \\
\text { (gram) }\end{array}$ & & $3059.8235 \pm 427.22058$ & & & \\
\hline
\end{tabular}


pregnancy, in which the mean level of maternal serum leptin in normal pregnancy and preeclampsia were $1588.7964 \pm$ $8.01074 \mathrm{ng} / \mathrm{mL}$ and $1608.1725 \pm 6.69579 \mathrm{ng} / \mathrm{m}$, respectively. The mean level of maternal serum leptin level was therefore statistically different between preeclampsia and normal pregnancy $(p<0.05)$. with the study conducted by Sumawan, et al. (19), there was no significant correlation between maternal leptin level and birth weight. Factors that influenced this result were the difference in the number, characteristic, selection

Table 2. Maternal Serum Leptin Level in Preeclampsia and Normal Pregnancy.

\begin{tabular}{lccc}
\hline & $\begin{array}{c}\text { Normal } \\
(\mathbf{n}=\mathbf{3 4})\end{array}$ & $\begin{array}{c}\text { Preeclampsia } \\
(\mathbf{n = 3 4 )}\end{array}$ & $\boldsymbol{p}$ \\
\hline $\begin{array}{l}\text { Leptin } \\
(\mathrm{ng} / \mathrm{mL})\end{array}$ & $1588.7964 \pm 8.01074$ & $1608.1725 \pm 6.69579$ & $\mathbf{0 . 0 0 0 0}$ \\
\hline
\end{tabular}

\section{Discussion}

There was no correlation in BMI between preeclampsia and normal pregnancy, which is probably due to similar BMI range of the samples in this study. There was extreme value obtained from sample number 64 with BMI $35 \mathrm{~kg} / \mathrm{m} 2$ in preeclamptic women. Since underweight samples were not excluded, this allow the extreme value to appear. In the study conducted by Noureldeen, et al. (17), there were no significant changes in circulating leptin level between normal and obese preeclamptic women. However, there was significant increase in leptin concentration of women with normal pregnancy and high BMI. This result might be associated with mobilization of maternal fat storage to increase availability and to support fat substrate intake transplacentally.(17) Salimi, et al. (18) conducted a study and found that there were correlation between leptin and BMI in normal pregnant women but not in preeclamptic women.(18)

There was a significant difference in birth weight between normal pregnant women and preeclamptic women. However, there were two extreme values. The first was a normal pregnancy that had body weight larger than its gestational age. This was resulted by gestational diabetes that should be tested for fetal blood glucose as well as maternal oral glucose tolerance to exclude the possibility of gestational diabetes. The second extreme value was obtained from normal pregnant women with preterm gestational age of 32-34 weeks, those who had premature labor with appropriate gestational age babies. In accordance criteria for subjects and BMI. In the study conducted by Mise, et al. (20), hypoxia and placental insufficiency was found to increase leptin level and may indicate hypothetical correlation between the increase of placental leptin secretion and the fetal growth retardation in severe preeclampsia. Placental insufficiency could lead to the increase of placental leptin production and suppression of fetal growth. Hyperleptinemia correlates with fetal growth retardation. Placental hypoperfusion could also result in local hypoxia that may increase leptin gene expression in placenta. There is possibility that the increase of leptin level in maternal circulation exacerbates hypertension since leptin activates sympathetic nerve system and stimulates catecholamine secretion. Therefore, maternal leptin level may describe fetoplacental condition in pregnancy with fetal growth disorder.

The results of this study showed that maternal serum leptin level in preeclampsia increased significantly as compared to that in normal pregnancy which is in accordance with previous conducted studies.(19) Some other studies, however, showed different results in which there was a decrease or constant leptin level in preeclampsia.(21) Several other studies showed similar results with this study such as those conducted by Mise, et al. (20) and Khosrowbeygi, et al. (22), where they found a significant increase in maternal serum leptin level in preeclamptic women as compared to normal pregnant women.(22) Mumtaz, et al., found a significant increase in leptin level in preeclampsia which was positively correlated with gestational age.(8) Similar findings were also found by Salimi, et al., where there was a significant increase in leptin level in preeclamptic women 
as compared to normal pregnant women, and this increase had direct correlation with the severity of preeclampsia as compared to adiponektin.(18)

In normal pregnancy, trophoblastic cells is the main source of leptin production. In situation where uteroplacental flow is confronted with stress, leptin will be produced in a plenty amount. A study conducted by $\mathrm{Bi}$, et al. showed a strong evidence that placenta may play a role in leptin concentration increase during pregnancy.(23) This negative feedback will rise leptin level which increases nutrition intake in placenta that has poor perfusion in preeclampsia.

In this study, there was a difficulty in sample storing and transfer, because blood drawing and processing was conducted in two different places. This could influence leptin result due to lysis of some samples during storing and transferring. Variation in BMI characteristic of sample could be a confounding factor and thus, BMI should be included as exclusion criteria in sample selection for this study.

\section{Conclusions}

The mean concentration of serum leptin in preeclamptic women was $1608.1725 \pm 6.69579 \mathrm{ng} / \mathrm{mL}$ and the mean concentration of serum leptin in normal pregnant women was $1588.7964 \pm 8.01074 \mathrm{ng} / \mathrm{mL}$. There was significant difference in leptin level between preeclamptic and normal pregnant women with $p<0.001$.

\section{References}

1. Anderson CM, Lopez F, Zhang HY, Pavlish K, Benoit JN. Characterization of Changes in Leptin and Leptin Receptors in A Rat Model of Preeclampsia. Am J Obstet Gynecol. 2005; 193: 26772.

2. Telang MA, Bhutkar SP, Hirwani, RR. Analysis of Patents on Preeclampsia Detection and Diagnosis: A perspective. Placenta. 2013; 34: 2-8.

3. Roshadi R. Hipertensi Dalam Kehamilan. In: Hariadi R. Ilmu Kedokteran Fetomaternal. Surabaya: Himpunan Kedokteran Fetomaternal Perhimpunan Obstetridan Ginekologi Indonesia; 2004. p.494-500.

4. Madi J, Sulin D. Angka Kematian Pasien Preeklampsia dan Eklampsia di RS.Dr. M. Djamil Padang tahun 1998-2002. Padang: Bagian Obstetri dan Ginekologi FK Universitas Andalas/RS. Dr. Djamil; 2003.
5. Serudji J. Minimizing Occurence and Complication of Preeclampsia. Pertemuan Ilmiah Tahunan Fetomaternal XIII, Palembang, Sumatera Selatan. 2013.

6. Sibai BM, Mercer BM, Schiff E, Friedman SA. Aggresive versus Expectant Management of Severe Preeclampsia at 28 to 32 weeks of Gestational: A Randomized Control Trial. Am J Obst Gynecol. 1994; 171: 818-22.

7. Cunningham FG, Leveno KJ, Bloom SL, Hauth JC., Gilstrap L, Wenstrom KD. Williams Obstetrics. 23rd ed. New York: The McGraw-Hill Companies; 2010.

8. Mumtaz F, Memon AR, Yousfani S, Tahir SM, Khushk I, Memon M, et al. Role Of Serum Leptin Level As A Marker Of Severity Of Preeclampsia. J Ayub Med Coll Abbottabad. 2008; 20: 13-5.

9. Saylik SA, Alkis I, Bayram N, Tuna V, Imamoglu N, Ceylan Y. Maternal Serum Leptin Level in Severe Preeclamptic Pregnant Women in Early Postpartum Stage. Int J Med Med Sci. 2009; 1: 248-53.

10. Yura S, Sagawa N, Mise H, Mori T, Masuzaki H, Ogawa Y, et al. A Positive Umbilical Venous-Arterial DIfference of Leptin Level and Its Rapid Decline After Birth. Am J Obstet Gynecol. 1998; 178: 926-30.

11. Khosrowbeygi A, Lorzadeh N, Ahmadvand H. Lipid Peroxidation Is Not Associated With Adipocytokin in Preeklampsia Women. Iran J Reprod Med. 2011; 9: 113-8.

12. Ahima RS, Osei SY. Leptin Signaling. Physiol Behav. 2004; 81: 223 41.

13. Tessier DR, Ferraro ZM, Gruslin, A. Role of Leptin in Pregnancy: Consequences of Maternal Obesity. Placenta. 2013; 34: 205-11.

14. Nanda S, Akolekar R, Acosta IC, Wierzbicka D, Nicolaides KH. Maternal Serum Leptin at 11-13 Weeks Gestation in Normal and Pathological Pregnancies. J Metabolic Synd. 2012; 1: 4. doi: 10.4172/2167-0943.1000113.

15. Huppertz B. Placental Origins of Preeclampsia: Challenging the Current Hypothesis. Hypertension. 2008; 51: 970-5.

16. Hauguel-de Mouzon S, Lepercq J, Catalano P. The Known and Unknown of Leptin in Pregnancy. Am J Obstet Gynecol. 2006; 194: 1537-45.

17. Noureldeen AFH, Qusti SY, Al-seeni MN. Serum Leptin, Adiponectin, Resistin, Visfatin and Inflammatory Cytokines in Normal Weight and Obese Women With Normal Pregnancy and With Preeclampsia. Life Sci. 2014; 11: 17-23.

18. Salimi S, Farajian-Mashhadi F, Naghavi A, Mokhtari M, Shahrakipour M, Saravani M, et al. Different Profile of Serum Leptin Between Early Onset and Late Onset Preeclampsia. Dis Markers. 2014; 2014: 628476. doi: 10.1155/2014/628476.

19. Sumawan H, Purwara BH, Krisnadi SR. Low Maternal Leptin Levels in Preeclamptic Women with Fetal Growth Restriction. Open J Obstet Gynecol. 2013; 3: 536-40.

20. Mise H, Sagawa N, Matsumoto T, Yura S, Nanno H, Itoh H, et al. Augmented Placental Production of Leptin in Preeclampsia : Possible Involvement of Placental Hypoxia. J Clin Endocrinol Metab.1998; 83: 3225-9.

21. Laml T, Preyer O, Hartmann BW, Ruecklinger E, Soeregi G, Wagenbichler P. Decreased Maternal Serum Leptin in Pregnancies Complicated by Preeclampsia. J Soc Gynecol Investig. 2001; 8: 8993.

22. Khosrowbeygi A, Ahmadvand H. Leptin to Adiponectin Ratio in Preeclampsia. Bangladesh Med Res Counc Bull. 2013; 39: 18-21.

23. Bi S, Gavrilova O, Gong DW, Mason MM, Reitman M. Identification 
on a Placental Enhancer For The Human Leptin Gene. J Biol Chem. 1997; 272: 30583-8.

24. Toro AR, Maymó JL, Ibarbalz FM, Pérez Pérez A, Maskin B, Faletti
AG, et al. Leptin is Anti-Apoptotic Effector in Placental Cells Involving p53 Downregulation. PLoS One. 2014; 9: e99187. doi: 10.1371/journal.pone.0099187. 